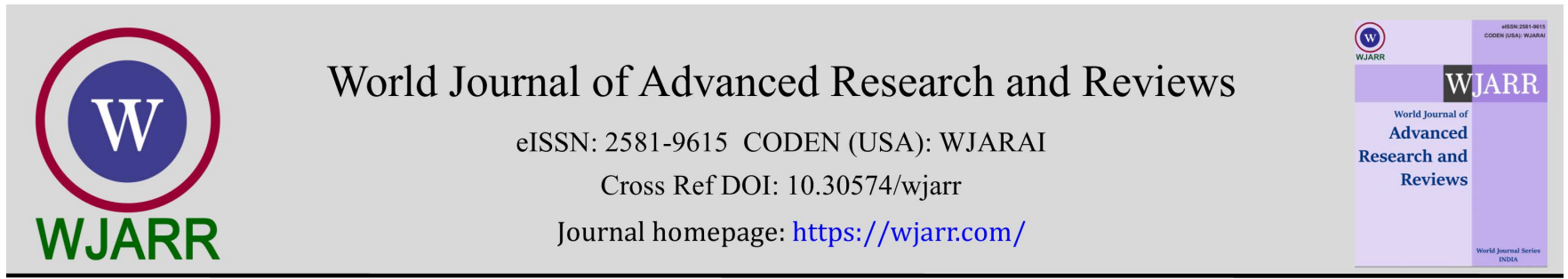

(RESEARCH ARTiClE)

\title{
Content of 31 trace elements in thyroid malignant nodules and thyroid tissue adjacent to nodules investigated using neutron activation analysis and inductively coupled plasma mass spectrometry
}

\author{
Vladimir Zaichick * \\ Radionuclide Diagnostics Department Medical Radiological Research Centre Obninsk, Russia.
}

World Journal of Advanced Research and Reviews, 2022, 13(01), 718-733

Publication history: Received on 22 December 2021; revised on 27 January 2022; accepted on 29 January 2022

Article DOI: https://doi.org/10.30574/wjarr.2022.13.1.0094

\begin{abstract}
Thyroid malignant nodules (TMNs) are the most common endocrine cancer and the fifth most frequently occurring type of malignancies. Women are at particular risk for this thyroid disease The etiology and pathogenesis of TMNs must be considered as multifactorial. The present study was performed to clarify the role of some trace elements (TEs) in the etiology of these thyroid disorders. Thyroid tissue levels of silver (Ag), aluminum (Al), boron (B),, beryllium (Be), bismuth (Bi), cadmium (Cd), cerium (Ce), cobalt (Co), chromium (Cr), cesium (Cs), iron (Fe), gallium (Ga), mercury (Hg), lanthanum (La), lithium (Li), manganese (Mn), molybdenum (Mo), neodymium (Nd), nickel (Ni), lead (Pb), praseodymium (Pr), rubidium (Rb), antimony (Sb), scandium (Sc), selenium (Se), samarium (Sm), tin (Sn), thallium (Tl), uranium (U), yttrium (Y), and zinc (Zn) were prospectively evaluated in malignant tumor and thyroid tissue adjacent to tumor of 41 patients with TMNs. Measurements were performed using a combination of non-destructive instrumental neutron activation analysis and destructive method such as inductively coupled plasma mass spectrometry. Results of the study were additionally compared with previously obtained data for the same TEs in "normal" thyroid tissue. It was observed that main characteristics of TMNs in comparison with "normal" thyroid were significantly elevated levels of $\mathrm{Ag}, \mathrm{Al}, \mathrm{B}, \mathrm{Bi}, \mathrm{Ce}, \mathrm{Cr}, \mathrm{Hg}, \mathrm{Mn}, \mathrm{Mo}, \mathrm{Ni}, \mathrm{Pb}, \mathrm{Rb}, \mathrm{Sm}$, and Tl. Furthermore, the TEs composition of thyroid tissue adjacent to tumor did not equal TEs contents of "normal" thyroid. Moreover, contents of such elements as Ag, Hg, and Se in adjacent tissue were higher than in tumor. Thus, from results obtained, it was possible to conclude that at least the excessive accumulation of $\mathrm{Ag}, \mathrm{Hg}$, and Se by thyroid tissue is likely to precede the TMNs origination and development. Elevated levels of $\mathrm{Ag}, \mathrm{Al}, \mathrm{B}, \mathrm{Bi}, \mathrm{Ce}, \mathrm{Cr}, \mathrm{Hg}, \mathrm{Mn}, \mathrm{Mo}, \mathrm{Ni}, \mathrm{Pb}, \mathrm{Rb}, \mathrm{Sm}$, and $\mathrm{Tl}$ in nodular tissue could possibly be explored for differential diagnosis of benign and malignant thyroid nodules.
\end{abstract}

Keywords: Thyroid; Thyroid malignant nodules; Trace elements; Neutron activation analysis

\section{Introduction}

Thyroid malignant nodules (TMNs) are the most common endocrine cancer and the fifth most frequently occurring type of malignancies [1-3]. Women are at particular risk for this thyroid disease with 22.2/100,000 individuals affected every year [2]. The incidence of TMNs has increased worldwide over the past four decades. TMNs are divided into three main histological types: differentiated (papillary and follicular thyroid cancer), undifferentiated (poorly differentiated and anaplastic thyroid cancer, and medullary thyroid cancer, arising from C cells of thyroid [3]. For over 20th century, there was the dominant opinion that TMNs is the simple consequence of iodine deficiency [4]. However, it was found that TMNs is a frequent disease even in those countries and regions where the population is never exposed to iodine shortage. Moreover, it was shown that iodine excess has severe consequences on human health and associated with the presence of TMNs [5-8]. It was also demonstrated that besides the iodine deficiency and excess many other dietary,

\footnotetext{
${ }^{*}$ Corresponding author: Vladimir Zaichick

Radionuclide Diagnostics Department Medical Radiological Research Centre Obninsk, Russia.
}

Copyright $(2022$ Author(s) retain the copyright of this article. This article is published under the terms of the Creative Commons Attribution Liscense 4.0. 
environmental, and occupational factors are associated with the TMNs incidence [9-11]. Among these factors a disturbance of evolutionary stable input of many trace elements (TEs) in human body after industrial revolution plays a significant role in etiology of TMNs [12].

Besides iodine, many other TEs have also essential physiological functions [13]. Essential or toxic (goitrogenic, mutagenic, carcinogenic) properties of TEs depend on tissue-specific need or tolerance, respectively [13]. Excessive accumulation or an imbalance of the TEs may disturb the cell functions and may result in cellular proliferation, degeneration, death, benign or malignant transformation [13-15].

In our previous studies the complex of in vivo and in vitro nuclear analytical and related methods was developed and used for the investigation of iodine and other TEs contents in the normal and pathological thyroid [16-22]. Iodine level in the normal thyroid was investigated in relation to age, gender and some non-thyroidal diseases [23,24]. After that, variations of many TEs content with age in the thyroid of males and females were studied and age- and genderdependence of some TEs was observed [25-41]. Furthermore, a significant difference between some TEs contents in colloid goiter, thyroiditis, and thyroid adenoma in comparison with normal thyroid was demonstrated [42-49].

To date, the etiology and pathogenesis of TMNs must be considered as multifactorial. The present study was performed to find out differences in TEs contents between the group of cancerous tissue and thyroid visually intact tissue adjacent to tumor, as well as to clarify the role of some TEs in the etiology of TMNs. Having this in mind, the aim of this exploratory study was to examine differences in the content of silver (Ag), aluminum (Al), boron (B),, beryllium (Be), bismuth (Bi), cadmium (Cd), cerium (Ce), cobalt (Co), chromium (Cr), cesium (Cs), iron (Fe), gallium (Ga), mercury (Hg), lanthanum (La), lithium (Li), manganese (Mn), molybdenum (Mo), neodymium (Nd), nickel (Ni), lead (Pb), praseodymium (Pr), rubidium $(\mathrm{Rb})$, antimony (Sb), scandium (Sc), selenium (Se), samarium (Sm), tin (Sn), thallium (Tl), uranium (U), yttrium (Y), and zinc ( $\mathrm{Zn}$ ) in tumor and adjacent to tumor tissues of thyroids with TMNs using a combination of nondestructive instrumental neutron activation analysis with high resolution spectrometry of long-lived radionuclides (INAA-LLR) and destructive method such as inductively coupled plasma mass spectrometry (ICP-MS), and to compare the levels of these TEs in two groups (tumor and thyroid tissues adjacent to tumor) of the cohort of TMNs samples. Moreover, for understanding a possible role of TEs in etiology and pathogenesis of TMNs results of the study were compared with previously obtained data for the same TEs in "normal" thyroid tissue [42-49]

\section{Material and methods}

All patients with TMNs ( $n=41$, mean age $M \pm S D$ was 46 \pm 15 years, range 16-75) were hospitalized in the Head and Neck Department of the Medical Radiological Research Centre (MRRC), Obninsk.. Thick-needle puncture biopsy of suspicious nodules of the thyroid was performed for every patient, to permit morphological study of thyroid tissue at these sites and to estimate their trace element contents. In all cases the diagnosis has been confirmed by clinical and morphological results obtained during studies of biopsy and resected materials. Histological conclusions for malignant tumors were: 25 papillary adenocarcinomas, 8 follicular adenocarcinomas, 7 solid carcinomas, and 1 reticulosarcoma. Tissue samples of tumor and visually intact tissue adjacent to tumor were taken from resected materials.

"Normal" thyroids for the control group samples were removed at necropsy from 105 deceased (mean age $44 \pm 21$ years, range 2-87), who had died suddenly. The majority of deaths were due to trauma. A histological examination in the control group was used to control the age norm conformity, as well as to confirm the absence of micro-nodules and latent cancer.

All studies were approved by the Ethical Committees of MRRC. All the procedures performed in studies involving human participants were in accordance with the ethical standards of the institutional and/or national research committee and with the 1964 Helsinki declaration and its later amendments, or with comparable ethical standards. Informed consent was obtained from all individual participants included in the study

All tissue samples obtained from tumors and visually intact tissue adjacent to tumors were divided into two portions using a titanium scalpel to prevent contamination by TEs of stainless steel [50]. One was used for morphological study while the other was intended for TEs analysis. After the samples intended for TEs analysis were weighed, they were freeze-dried and homogenized [51].

The pounded samples weighing about $10 \mathrm{mg}$ (for biopsy) and $100 \mathrm{mg}$ (for resected materials) were used for TEs measurement by INAA-LLR. The content of $\mathrm{Ag}$, $\mathrm{Co}, \mathrm{Cr}, \mathrm{Fe}, \mathrm{Hg}, \mathrm{Rb}, \mathrm{Sb}, \mathrm{Sc}$, Se, and Zn were determined by INAA-LLR using a vertical channel of the Water-Water-Research nuclear reactor (Branch of Karpov Institute, Obninsk). After non- 
destructive INAA-LLR investigation the thyroid samples were used for ICP-MS. The samples were decomposed in autoclaves and aliquots of solutions were used to determine the $\mathrm{Ag}$, $\mathrm{Al}, \mathrm{B}, \mathrm{Be}, \mathrm{Bi}, \mathrm{Cd}, \mathrm{Ce}, \mathrm{Co}, \mathrm{Cr}, \mathrm{Cs}, \mathrm{Fe}, \mathrm{Ga}, \mathrm{Hg}, \mathrm{La}, \mathrm{Li}, \mathrm{Mn}$, Mo, Nd, Ni, Pb, Pr, Rb, Sb, Sc, Se, Sm, Sn, Tl, U, Y, and Zn mass fractions by ICP-MS using an ICP-MS Thermo-Fisher "X-7" Spectrometer (Thermo Electron, USA). Information detailing with the NAA-LLR and ICP-MS methods used and other details of the analysis were presented in our earlier publications concerning TE contents in human thyroid $\{29,30,35]$, prostate [52-57], and scalp hair [58].

To determine contents of the TEs by comparison with a known standard, biological synthetic standards (BSS) prepared from phenol-formaldehyde resins were used [59]. In addition to BSS, aliquots of commercial, chemically pure compounds were also used as standards. Ten sub-samples of certified reference material (CRM) IAEA H-4 (animal muscle) and five sub-samples of CRM of the Institute of Nuclear Chemistry and Technology (INCT, Warszawa, Poland) INCT-SBF-4 Soya Bean Flour, INCT-TL-1 Tea Leaves, and INCT-MPH-2 Mixed Polish Herbs were treated and analyzed in the same conditions that thyroid samples to estimate the precision and accuracy of results

A dedicated computer program for INAA-LLR mode optimization was used [60]. All thyroid samples were prepared in duplicate, and mean values of TEs contents were used in final calculation. Mean values of TEs contents were used in final calculation for the $\mathrm{Ag}, \mathrm{Co}, \mathrm{Cr}, \mathrm{Hg}, \mathrm{Rb}, \mathrm{Sb}, \mathrm{Se}$, and $\mathrm{Zn}$ mass fractions measured by INAA-LLR and ICP-MS methods. Using Microsoft Office Excel software, a summary of the statistics, including, arithmetic mean, standard deviation of mean, standard error of mean, minimum and maximum values, median, percentiles with 0.025 and 0.975 levels was calculated for TEs contents in nodular and adjacent tissue of thyroids with TMNs. Data for "normal" thyroid were taken from our previous publications [42-49]. The difference in the results between three groups of samples ("normal", "tumor", and "adjacent") was evaluated by the parametric Student's $t$-test and non-parametric Wilcoxon-Mann-Whitney $U$-test.

\section{Results}

Table 1 presents certain statistical parameters (arithmetic mean, standard deviation of mean, minimal and maximal values) of the $\mathrm{Ag}$, Al, B, Be, Bi, Cd, Ce, Co, Cr, Cs, Fe, Ga, Hg, La, Li, Mn, Mo, Nd, Ni, Pb, Pr, Rb, Sb, Sc, Se, Sm, Sn, Tl, U, Y, and Zn mass fraction in "tumor" and "adjacent" groups of thyroid tissue samples.

The ratios of means and the comparison of mean values of $\mathrm{Ag}, \mathrm{Al}, \mathrm{B}, \mathrm{Be}, \mathrm{Bi}, \mathrm{Cd}, \mathrm{Ce}, \mathrm{Co}, \mathrm{Cr}, \mathrm{Cs}, \mathrm{Fe}, \mathrm{Ga}, \mathrm{Hg}, \mathrm{La}, \mathrm{Li}, \mathrm{Mn}, \mathrm{Mo}$, $\mathrm{Nd}, \mathrm{Ni}, \mathrm{Pb}, \mathrm{Pr}, \mathrm{Rb}, \mathrm{Sb}, \mathrm{Sc}$, Se, Sm, Sn, Tl, U, Y, and Zn mass fractions in pairs of sample groups such as "normal" and "tumor", "normal" and "adjacent", and also "adjacent" and "tumor" are presented in Table 2, 3, and 4, respectively.

Table 1 Some statistical parameters of 31 trace element mass fraction (mg/kg, dry mass basis) in the thyroid malignant nodules (TMN) and thyroid tissue adjacent to tumor

\begin{tabular}{|l|c|c|c|c|c|c|}
\hline \multirow{2}{*}{ Element } & \multicolumn{2}{|c|}{ Thyroid malignant nodules (tumor) } & \multicolumn{2}{c|}{ Thyroid tissue adjacent to tumor } \\
\cline { 2 - 7 } & M & SD & Range & M & SD & Range \\
\hline $\mathrm{Ag}$ & 0.139 & 0.141 & $0.00750-0.536$ & 0.432 & 0.291 & $0.00790-1.00$ \\
\hline $\mathrm{Al}$ & 33.0 & 25.5 & $4.50-96.5$ & 19.4 & 11.1 & $7.10-32.9$ \\
\hline $\mathrm{B}$ & 2.21 & 1.89 & $1.00-5.6$ & 5.80 & 9.60 & $1.00-20.2$ \\
\hline $\mathrm{Be}$ & 0.00047 & 0.00013 & $0.000200-0.000720$ & $<0.0002$ & - & - \\
\hline $\mathrm{Bi}$ & 0.067 & 0.083 & $0.00480-0.335$ & 0.082 & 0.039 & $0.0427-0.136$ \\
\hline $\mathrm{Cd}$ & 1.13 & 1.82 & $0.0290-6.83$ & 6.83 & 12.5 & $0.059-25.5$ \\
\hline $\mathrm{Ce}$ & 0.0277 & 0.0275 & $0.00470-0.0874$ & 0.0085 & 0.0061 & $0.00490-0.0176$ \\
\hline $\mathrm{Co}$ & 0.0499 & 0.0292 & $0.00420-0.143$ & 0.068 & 0.058 & $0.0152-0.205$ \\
\hline $\mathrm{Cr}$ & 0.847 & 0.811 & $0.0390-3.50$ & 0.642 & 0.491 & $0.0512-1.58$ \\
\hline $\mathrm{Cs}$ & 0.0298 & 0.0287 & $0.00660-0.112$ & 0.0166 & 0.0057 & $0.0102-0.0240$ \\
\hline $\mathrm{Fe}$ & 255 & 168 & $60.6-880$ & 256 & 133 & $109-752$ \\
\hline $\mathrm{Ga}$ & 0.0342 & 0.0111 & $0.0200-0.0640$ & 0.0273 & 0.0159 & $0.0100-0.0470$ \\
\hline
\end{tabular}




\begin{tabular}{|l|c|c|c|c|c|c|}
\hline $\mathrm{Hg}$ & 0.915 & 0.826 & $0.0685-3.75$ & 2.24 & 1.87 & $0.253-7.78$ \\
\hline $\mathrm{La}$ & 0.0134 & 0.0124 & $0.00430-0.0443$ & 0.0043 & 0.0029 & $0.00210-0.00760$ \\
\hline $\mathrm{Li}$ & 0.0315 & 0.0307 & $0.00780-0.111$ & 0.021 & 0.020 & $0.0096-0.0514$ \\
\hline $\mathrm{Mn}$ & 2.01 & 1.34 & $0.100-5.95$ & 1.77 & 1.60 & $0.410-6.78$ \\
\hline $\mathrm{Mo}$ & 0.292 & 0.112 & $0.0936-0.534$ & 0.199 & 0.060 & $0.129-0.270$ \\
\hline $\mathrm{Nd}$ & 0.0156 & 0.0143 & $0.00330-0.0412$ & 0.0028 & 0.0029 & $0.00100-0.00710$ \\
\hline $\mathrm{Ni}$ & 4.38 & 2.24 & $0.270-7.30$ & 2.78 & 1.65 & $1.10-4.60$ \\
\hline $\mathrm{Pb}$ & 1.14 & 1.16 & $0.240-4.44$ & 0.69 & 0.87 & $0.220-2.00$ \\
\hline $\mathrm{Pr}$ & 0.0078 & 0.0130 & $0.000920-0.0463$ & 0.00107 & 0.00060 & $0.00051-0.00170$ \\
\hline $\mathrm{Rb}$ & 12.65 & 4.87 & $5.10-27.4$ & 18.9 & 17.0 & $5.00-67.0$ \\
\hline $\mathrm{Sb}$ & 0.107 & 0.075 & $0.0160-0.334$ & 0.248 & 0.415 & $0.00690-1.77$ \\
\hline $\mathrm{Sc}$ & 0.0077 & 0.0129 & $0.000200-0.0565$ & 0.0059 & 0.0134 & $0.000200-0.0539$ \\
\hline $\mathrm{Se}$ & 2.04 & 1.06 & $0.143-4.80$ & 3.08 & 1.67 & $0.704-6.91$ \\
\hline $\mathrm{Sm}$ & 0.00194 & 0.00174 & $0.000500-0.00670$ & $<0.0004$ & - & \\
\hline $\mathrm{Sn}$ & 0.0697 & 0.0487 & $0.0138-0.182$ & 0.071 & 0.096 & $0.0126-0.214$ \\
\hline $\mathrm{Tl}$ & 0.00307 & 0.00197 & $0.000600-0.00700$ & 0.0034 & 0.0021 & $0.00120-0.00600$ \\
\hline $\mathrm{U}$ & 0.00514 & 0.01109 & $0.000550-0.0326$ & 0.00115 & 0.00092 & $0.000500-0.00180$ \\
\hline $\mathrm{Y}$ & 0.0123 & 0.0117 & $0.00230-0.0343$ & 0.0039 & 0.0022 & $0.00230-0.00540$ \\
\hline $\mathrm{Zn}$ & 96.9 & 80.0 & $28.7-375$ & 111 & 55 & $20.4-272$ \\
\hline & & $\mathrm{M}-$ arithmetic mean, SD-standard deviation, Range- min-max values & \\
\hline
\end{tabular}

\section{Discussion}

As was shown before [29,30,35,52-58] good agreement of the 50 TE mass fractions in CRM IAEA H-4, INCT-SBF-4, INCTTL-1, and INCT-MPH-2 samples determined by both INAA-LLR and ICP-MS methods with the certified data of these CRMs indicates acceptable accuracy of the results obtained in the study of thyroid tissue samples presented in Tables $1-4$.

From Table 2, it was observed that in malignant tissue the mass fraction of $\mathrm{Ag}, \mathrm{Al}, \mathrm{B}, \mathrm{Bi}, \mathrm{Ce}, \mathrm{Cr}, \mathrm{Hg}, \mathrm{Mn}, \mathrm{Mo}, \mathrm{Ni}, \mathrm{Pb}, \mathrm{Rb}$, $\mathrm{Sm}$, and $\mathrm{Tl}$ were approximately $11,3.1,4.6,9.3,3.5,3.7,17,1.6,3.5,9.8,4.9,1.7,3.8$, and 3.3 times, respectively, higher, while Sc content 3.4 times lower than in normal tissues of the thyroid. In a general sense $\mathrm{Al}, \mathrm{B}, \mathrm{Be}, \mathrm{Cd}, \mathrm{Ce}, \mathrm{Cr}, \mathrm{Cs}, \mathrm{Fe}, \mathrm{Ga}$, $\mathrm{La}, \mathrm{Li}, \mathrm{Mn}, \mathrm{Nd}, \mathrm{Pb}, \mathrm{Pr}, \mathrm{Sb}, \mathrm{Sm}, \mathrm{Sn}, \mathrm{Tl}, \mathrm{U}, \mathrm{Y}$, and Zn contents found in the "normal" and "adjacent" groups of thyroid tissue samples were similar (Table 3). However, in the "adjacent" group mean mass fractions of $\mathrm{Ag}, \mathrm{Bi}, \mathrm{Co}, \mathrm{Hg}, \mathrm{Mo}, \mathrm{Ni}, \mathrm{Rb}$, and Se were approximately $33,11,1.7,41,2.4,6.2,2.5$, and 1.4 times, respectively, higher, than in the "normal" group of samples. Significant reduced levels of tumor TEs in comparison with thyroid tissue adjacent to tumor were found for $\mathrm{Ag}, \mathrm{Hg}$, and Se. In malignant tumor $\mathrm{Ag}, \mathrm{Hg}$, and Se contents were approximately 3.1, 2.4, and 1.5 times, respectively, lower than in "adjacent" group of tissue samples (Table 4).

Characteristically, elevated or reduced levels of TEs observed in thyroid nodules are discussed in terms of their potential role in the initiation and promotion of these thyroid lesions. In other words, using the low or high levels of the TEs in affected thyroid tissues researchers try to determine the role of the deficiency or excess of each TE in the etiology and pathogenesis of thyroid diseases. In our opinion, abnormal levels of many TEs in TMNs could be and cause, and also effect of thyroid tissue transformation. From the results of such kind studies, it is not always possible to decide whether the measured decrease or increase in TEs level in pathologically altered tissue is the reason for alterations or vice versa. According to our opinion, investigation of TEs contents in thyroid tissue adjacent to malignant nodules and comparison obtained results with TEs levels typical of "normal" thyroid gland may give additional useful information on the topic because these data show conditions of tissue in which TMNs were originated and developed. 
Table 2 Differences between mean values $(\mathrm{M} \pm \mathrm{SEM}$ ) of trace element mass fractions ( $\mathrm{mg} / \mathrm{kg}$, dry mass basis) in normal thyroid and thyroid malignant nodules (TMN tumor)

\begin{tabular}{|c|c|c|c|c|c|}
\hline \multirow[t]{2}{*}{ Element } & \multicolumn{4}{|c|}{ Thyroid tissue } & \multirow{2}{*}{$\begin{array}{l}\text { Ratio } \\
\text { tumor/NT }\end{array}$} \\
\hline & Normal thyroid (NT) & TMN tumor & Student's t-test $p \leq$ & U-test $p$ & \\
\hline $\mathrm{Ag}$ & $0.0133 \pm 0.0013$ & $0.139 \pm 0.028$ & 0.00013 & $\leq \mathbf{0 . 0 1}$ & 10.5 \\
\hline $\mathrm{Al}$ & $10.5 \pm 1.8$ & $33.0 \pm 7.1$ & 0.0083 & $\leq 0.01$ & 3.14 \\
\hline $\mathrm{B}$ & $0.476 \pm 0.058$ & $2.21 \pm 0.52$ & 0.0062 & $\leq 0.01$ & 4.64 \\
\hline $\mathrm{Be}$ & $0.00052 \pm 0.00008$ & $0.00047 \pm 0.00004$ & 0.589 & $>0.05$ & 0.90 \\
\hline $\mathrm{Bi}$ & $0.0072 \pm 0.0022$ & $0.067 \pm 0.023$ & 0.024 & $\leq 0.01$ & 9.31 \\
\hline $\mathrm{Cd}$ & $2.08 \pm 0.27$ & $1.13 \pm 0.49$ & 0.103 & $>0.05$ & 0.54 \\
\hline $\mathrm{Ce}$ & $0.0080 \pm 0.0011$ & $0.0277 \pm 0.0080$ & 0.025 & $\leq 0.01$ & 3.46 \\
\hline Co & $0.0390 \pm 0.0031$ & $0.0499 \pm 0.0050$ & 0.082 & $>0.05$ & 1.28 \\
\hline $\mathrm{Cr}$ & $0.495 \pm 0.031$ & $0.847 \pm 0.148$ & 0.026 & $\leq 0.01$ & 3.74 \\
\hline Cs & $0.0245 \pm 0.0022$ & $0.0298 \pm 0.0090$ & 0.573 & $>0.05$ & 1.22 \\
\hline $\mathrm{Fe}$ & $222.8 \pm 9.6$ & $255 \pm 27$ & 0.270 & $>0.05$ & 1.14 \\
\hline $\mathrm{Ga}$ & $0.0316 \pm 0.0021$ & $0.0342 \pm 0.0030$ & 0.519 & $>0.05$ & 1.08 \\
\hline $\mathrm{Hg}$ & $0.0543 \pm 0.0043$ & $0.915 \pm 0.146$ & 0.000001 & $\leq 0.01$ & 16.9 \\
\hline $\mathrm{La}$ & $0.00475 \pm 0.00062$ & $0.0134 \pm 0.0040$ & 0.070 & $>0.05$ & 2.82 \\
\hline $\mathrm{Li}$ & $0.0208 \pm 0.0022$ & $0.0315 \pm 0.0090$ & 0.265 & $>0.05$ & 1.51 \\
\hline $\mathrm{Mn}$ & $1.28 \pm 0.07$ & $2.01 \pm 0.29$ & 0.025 & $\leq 0.01$ & 1.57 \\
\hline Mo & $0.0836 \pm 0.0062$ & $0.292 \pm 0.031$ & 0.000017 & $\leq 0.01$ & 3.49 \\
\hline $\mathrm{Nd}$ & $0.0041 \pm 0.0004$ & $0.0156 \pm 0.0050$ & 0.056 & $>0.05$ & 3.80 \\
\hline $\mathrm{Ni}$ & $0.449 \pm 0.046$ & $4.38 \pm 0.65$ & 0.000079 & $\leq 0.01$ & 9.76 \\
\hline $\mathrm{Pb}$ & $0.233 \pm 0.033$ & $1.14 \pm 0.33$ & 0.020 & $\leq 0.01$ & 4.89 \\
\hline $\operatorname{Pr}$ & $0.00107 \pm 0.00011$ & $0.0078 \pm 0.0040$ & 0.115 & $>0.05$ & 7.29 \\
\hline $\mathrm{Rb}$ & $7.54 \pm 0.39$ & $12.65 \pm 0.76$ & 0.000001 & $\leq 0.01$ & 1.68 \\
\hline $\mathrm{Sb}$ & $0.0947 \pm 0.0075$ & $0.107 \pm 0.014$ & 0.388 & $>0.05$ & 1.13 \\
\hline Sc & $0.0268 \pm 0.0060$ & $0.0077 \pm 0.0020$ & 0.0053 & $\leq 0.01$ & 0.29 \\
\hline $\mathrm{Se}$ & $2.22 \pm 0.14$ & $2.04 \pm 0.19$ & 0.457 & $>0.05$ & 0.92 \\
\hline $\mathrm{Sm}$ & $0.000507 \pm 0.000064$ & $0.00194 \pm 0.00048$ & 0.012 & $\leq 0.01$ & 3,83 \\
\hline Sn & $0.0777 \pm 0.0091$ & $0.0697 \pm 0.0140$ & 0.627 & $>0.05$ & 0.90 \\
\hline $\mathrm{Tl}$ & $0.00093 \pm .0 .00007$ & $0.00307 \pm 0.00100$ & 0.0020 & $\leq 0.01$ & 3.29 \\
\hline $\mathrm{U}$ & $0.000443 \pm 0.000059$ & $0.00514 \pm 0.00400$ & 0.270 & $>0.05$ & 11.6 \\
\hline $\mathrm{Y}$ & $0.00260 \pm 0.00032$ & $0.0123 \pm 0.0040$ & 0.071 & $>0.05$ & 4.73 \\
\hline $\mathrm{Zn}$ & $94.8 \pm 4.2$ & $96.9 \pm 12.6$ & 0.877 & $>0.05$ & 1.02 \\
\hline
\end{tabular}

M - Arithmetic mean, SEM - standard error of mean, statistically significant values are in bold 
Table 3 Differences between mean values ( $\mathrm{M} \pm \mathrm{SEM}$ ) of trace element mass fractions ( $\mathrm{mg} / \mathrm{kg}$, dry mass basis) in normal thyroid (NT) and thyroid tissue adjacent to thyroid malignant nodules (TMN)

\begin{tabular}{|c|c|c|c|c|c|}
\hline \multirow[t]{2}{*}{ Element } & \multicolumn{4}{|c|}{ Thyroid tissue } & \multirow{2}{*}{$\begin{array}{l}\text { Ratio } \\
\text { adjacent/NT }\end{array}$} \\
\hline & Normal thyroid (NT) & TMN adjacent & Student's t-test $p \leq$ & U-test $p$ & \\
\hline $\mathrm{Ag}$ & $0.0133 \pm 0.0013$ & $0.432 \pm 0.067$ & 0.0000064 & $\leq 0.01$ & 32.5 \\
\hline $\mathrm{Al}$ & $10.5 \pm 1.8$ & $19.4 \pm 5.6$ & 0.206 & $>0.05$ & 1.85 \\
\hline B & $0.476 \pm 0.058$ & $5.80 \pm 4.80$ & 0.348 & $>0.05$ & 12.2 \\
\hline $\mathrm{Be}$ & $0.00052 \pm 0.00008$ & $<0.0002$ & - & - & - \\
\hline $\mathrm{Bi}$ & $0.0072 \pm 0.0022$ & $0.082 \pm 0.020$ & 0.031 & $\leq 0.01$ & 11.4 \\
\hline $\mathrm{Cd}$ & $2.08 \pm 0.27$ & $6.83 \pm 6.2$ & 0.501 & $>0.05$ & 3.28 \\
\hline $\mathrm{Ce}$ & $0.0080 \pm 0.0011$ & $0.0085 \pm 0.0030$ & 0.883 & $>0.05$ & 1.06 \\
\hline Co & $0.039 \pm 0.003$ & $0.068 \pm 0.012$ & 0.021 & $\leq 0.01$ & 1.74 \\
\hline $\mathrm{Cr}$ & $0.495 \pm 0.031$ & $0.642 \pm 0.098$ & 0.164 & $>0.05$ & 1.30 \\
\hline Cs & $0.0245 \pm 0.0022$ & $0.0166 \pm 0.0030$ & 0.057 & $>0.05$ & 0.68 \\
\hline $\mathrm{Fe}$ & $222.8 \pm 9.6$ & $256 \pm 26$ & 0.244 & $>0.05$ & 1.15 \\
\hline $\mathrm{Ga}$ & $0.0316 \pm 0.0021$ & $0.0273 \pm 0.0080$ & 0.623 & $>0.05$ & 0.86 \\
\hline $\mathrm{Hg}$ & $0.0543 \pm 0.0043$ & $2.24 \pm 0.37$ & 0.0000049 & $\leq 0.01$ & 41.3 \\
\hline La & $0.0048 \pm 0.0006$ & $0.0043 \pm 0.0020$ & 0.810 & $>0.05$ & 0.90 \\
\hline $\mathrm{Li}$ & $0.0208 \pm 0.0022$ & $0.0210 \pm 0.0100$ & 0.989 & $>0.05$ & 1.01 \\
\hline $\mathrm{Mn}$ & $1.28 \pm 0.07$ & $1.77 \pm 0.40$ & 0.252 & $>0.05$ & 1.38 \\
\hline Mo & $0.0836 \pm 0.0062$ & $0.199 \pm 0.030$ & 0.028 & $\leq 0.01$ & 2.38 \\
\hline $\mathrm{Nd}$ & $0.0041 \pm 0.0004$ & $0.0028 \pm 0.0010$ & 0.457 & $>0.05$ & 0.68 \\
\hline $\mathrm{Ni}$ & $0.449 \pm 0.046$ & $2.78 \pm 0.82$ & 0.066 & $\leq 0.05$ & 6.19 \\
\hline $\mathrm{Pb}$ & $0.233 \pm 0.033$ & $0.69 \pm 0.44$ & 0.373 & $>0.05$ & 2.96 \\
\hline $\operatorname{Pr}$ & $0.00107 \pm 0.00011$ & $0.00107 \pm 0.00035$ & 0.999 & $>0.05$ & 1.00 \\
\hline $\mathrm{Rb}$ & $7.54 \pm 0.39$ & $18.9 \pm 3.3$ & 0.0024 & $\leq 0.01$ & 2.51 \\
\hline $\mathrm{Sb}$ & $0.0947 \pm 0.0075$ & $0.248 \pm 0.085$ & 0.085 & $>0.05$ & 2.62 \\
\hline $\mathrm{Sc}$ & $0.0268 \pm 0.0060$ & $0.0059 \pm 0.0030$ & 0.0029 & $\leq 0.01$ & 0.22 \\
\hline $\mathrm{Se}$ & $2.22 \pm 0.14$ & $3.08 \pm 0.33$ & 0.020 & $\leq 0.01$ & 1.39 \\
\hline $\mathrm{Sm}$ & $0.000507 \pm 0.000064$ & $<0.0004$ & - & - & - \\
\hline $\mathrm{Sn}$ & $0.078 \pm 0.009$ & $0.071 \pm 0.048$ & 0.897 & $>0.05$ & 0.91 \\
\hline $\mathrm{Tl}$ & $0.00093 \pm .0 .00007$ & $0.00340 \pm 0.00100$ & 0.099 & $>0.05$ & 3.66 \\
\hline $\mathrm{U}$ & $0.00044 \pm 0.00006$ & $0.00115 \pm 0.00065$ & 0.472 & $>0.05$ & 2.61 \\
\hline $\mathrm{Y}$ & $0.0026 \pm 0.0003$ & $0.0039 \pm 0.0016$ & 0.565 & $>0.05$ & 1.50 \\
\hline $\mathrm{Zn}$ & $94.8 \pm 4.2$ & $111 \pm 11$ & 0.175 & $>0.05$ & 1.17 \\
\hline
\end{tabular}


Table 4 Differences between mean values (M \pm SEM) of trace element mass fractions (mg/kg, dry mass basis) in thyroid malignant nodules (TMN) and thyroid tissue adjacent to nodules

\begin{tabular}{|c|c|c|c|c|c|}
\hline \multirow[t]{2}{*}{ Element } & \multicolumn{4}{|c|}{ Thyroid tissue } & \multirow{2}{*}{$\begin{array}{l}\text { Ratio } \\
\text { tumor/ adjacent }\end{array}$} \\
\hline & TMN adjacent & TMN tumor & Student's t-test $p \leq$ & U-test $p$ & \\
\hline $\mathrm{Ag}$ & $0.432 \pm 0.067$ & $0.139 \pm 0.028$ & 0.00045 & $\leq 0.01$ & 0.32 \\
\hline $\mathrm{Al}$ & $19.4 \pm 5.6$ & $33.0 \pm 7.1$ & 0.157 & $>0.05$ & 1.70 \\
\hline B & $5.80 \pm 4.80$ & $2.21 \pm 0.52$ & 0.510 & $>0.05$ & 0.38 \\
\hline $\mathrm{Be}$ & $<0.0002$ & $0.00047 \pm 0.00004$ & - & - & - \\
\hline $\mathrm{Bi}$ & $0.082 \pm 0.020$ & $0.067 \pm 0.023$ & 0.625 & $>0.05$ & 0.82 \\
\hline $\mathrm{Cd}$ & $6.83 \pm 6.2$ & $1.13 \pm 0.49$ & 0.428 & $>0.05$ & 0.17 \\
\hline $\mathrm{Ce}$ & $0.0085 \pm 0.0030$ & $0.0277 \pm 0.0080$ & 0.034 & $\leq 0.01$ & 3.26 \\
\hline Co & $0.068 \pm 0.012$ & $0.050 \pm 0.005$ & 0.158 & $>0.05$ & 0.74 \\
\hline $\mathrm{Cr}$ & $0.642 \pm 0.098$ & $0.847 \pm 0.148$ & 0.253 & $>0.05$ & 1.32 \\
\hline Cs & $0.0166 \pm 0.0030$ & $0.0298 \pm 0.0090$ & 0.173 & $>0.05$ & 1.80 \\
\hline $\mathrm{Fe}$ & $256 \pm 26$ & $255 \pm 27$ & 0.982 & $>0.05$ & 1.00 \\
\hline $\mathrm{Ga}$ & $0.0273 \pm 0.0080$ & $0.0342 \pm 0.0030$ & 0.467 & $>0.05$ & 1.25 \\
\hline $\mathrm{Hg}$ & $2.24 \pm 0.37$ & $0.915 \pm 0.146$ & 0.0024 & $\leq 0.01$ & 0.41 \\
\hline $\mathrm{La}$ & $0.0043 \pm 0.0020$ & $0.0134 \pm 0.0040$ & 0.068 & $>0.05$ & 3.12 \\
\hline $\mathrm{Li}$ & $0.0210 \pm 0.0100$ & $0.0315 \pm 0.0090$ & 0.458 & $>0.05$ & 1.50 \\
\hline $\mathrm{Mn}$ & $1.77 \pm 0.40$ & $2.01 \pm 0.29$ & 0.629 & $>0.05$ & 1.14 \\
\hline Mo & $0.199 \pm 0.030$ & $0.292 \pm 0.031$ & 0.056 & $>0.05$ & 1.47 \\
\hline $\mathrm{Nd}$ & $0.0028 \pm 0.0010$ & $0.0156 \pm 0.0050$ & 0.041 & $\leq 0.01$ & 5.57 \\
\hline $\mathrm{Ni}$ & $2.78 \pm 0.82$ & $4.38 \pm 0.65$ & 0.169 & $>0.05$ & 1.58 \\
\hline $\mathrm{Pb}$ & $0.69 \pm 0.44$ & $1.14 \pm 0.33$ & 0.437 & $>0.05$ & 1.65 \\
\hline Pr & $0.0011 \pm 0.0004$ & $0.0078 \pm 0.0040$ & 0.116 & $>0.05$ & 7.29 \\
\hline $\mathrm{Rb}$ & $18.9 \pm 3.3$ & $12.7 \pm 0.8$ & 0.081 & $>0.05$ & 0.67 \\
\hline $\mathrm{Sb}$ & $0.248 \pm 0.085$ & $0.107 \pm 0.014$ & 0.118 & $>0.05$ & 0.43 \\
\hline $\mathrm{Sc}$ & $0.0059 \pm 0.0030$ & $0.0077 \pm 0.0020$ & 0.624 & $>0.05$ & 1.31 \\
\hline $\mathrm{Se}$ & $3.08 \pm 0.33$ & $2.04 \pm 0.19$ & 0.0093 & $\leq 0.01$ & 0.66 \\
\hline $\mathrm{Sm}$ & $<0.0004$ & $0.00194 \pm 0.00048$ & - & - & - \\
\hline $\mathrm{Sn}$ & $0.071 \pm 0.048$ & $0.070 \pm 0.014$ & 0.982 & $>0.05$ & 0.99 \\
\hline $\mathrm{Tl}$ & $0.0034 \pm 0.00100$ & $0.0031 \pm 0.0010$ & 0.805 & $>0.05$ & 0.91 \\
\hline $\mathrm{U}$ & $0.00115 \pm 0.00065$ & $0.00514 \pm 0.00400$ & 0.348 & $>0.05$ & 4.47 \\
\hline Y & $0.0039 \pm 0.0016$ & $0.0123 \pm 0.0040$ & 0.116 & $>0.05$ & 3.15 \\
\hline $\mathrm{Zn}$ & $111 \pm 11$ & $96.9 \pm 12.6$ & 0.403 & $>0.05$ & 0.87 \\
\hline
\end{tabular}

Thus, from results obtained, it was possible to conclude that the main characteristics of TMNs in comparison with "normal" thyroid were significantly elevated levels of Ag, Al, B, Bi, Ce, Cr, Hg, Mn, Mo, Ni, Pb, Rb, Sm, and Tl (Table 2). Furthermore, the TEs composition of thyroid tissue adjacent to tumor did not equal TEs contents of "normal" thyroid 
(Table 3). Moreover, contents of such elements as Ag, $\mathrm{Hg}$, and Se in adjacent tissue were higher than in tumor (Table 4). From this it follows that at least the excessive accumulation of $\mathrm{Ag}, \mathrm{Hg}$, and Se by thyroid tissue is likely to precede the TMNs origination and development.

\subsection{Silver}

Ag is a trace metal with no recognized value in the human body [61]. Food is the major intake source of Ag and this metal is authorised as a food additive (E174) in the EU [62]. Another source of Ag is contact with skin and mucosal surfaces because Ag is widely used in different applications (e.g., jewelry, wound dressings, or eye drops) [63]. Ag in metal form and inorganic Ag compounds ionize in the presence of water, body fluids or tissue exudates. The silver ion $\mathrm{Ag}^{+}$is biologically active and readily interacts with proteins, amino acid residues, free anions and receptors on mammalian and eukaryotic cell membranes [64]. Besides such the adverse effects of chronic exposure to Ag as a permanent bluish-gray discoloration of the skin (argyria) or eyes (argyrosis), exposure to soluble Ag compounds may produce other toxic effects, including liver and kidney damage, irritation of the eyes, skin, respiratory, and intestinal tract, and changes in blood cells [65]. Experimental studies shown that Ag nanoparticles may affect thyroid hormone metabolism [66]. More detailed knowledge of the Ag toxicity can lead to a better understanding of the impact on human health, including thyroid function.

\subsection{Aluminum}

$\mathrm{Al}$ is the most widely distributed metal in the environment. Environmental media may be contaminated by Al from anthropogenic sources and through the weathering of rocks and minerals [67]. The trace element Al is not described as essential, because no biochemical function has been directly connected to it. Toxic actions of Al induce oxidative stress, immunologic alterations, genotoxicity, and other disorders, including cell membrane perturbation, apoptosis, necrosis and dysplasia [67]. Furthermore, it was shown in experimental and epidemiological studies that Al can affect thyroid iodide uptake and hormones secretion $[68,69]$.

\subsection{Boron}

Trace element B is known to influence the activity of many enzymes [70]. Numerous studies have demonstrated beneficial effects of $\mathrm{B}$ on human health, including anti-inflammatory stimulus - reduces levels of inflammatory biomarkers, such as high-sensitivity C-reactive protein (hs-CRP) and tumor necrosis factor $\alpha$ (TNF- $\alpha$ ); as well as raises levels of antioxidant enzymes, such as superoxide dismutase (SOD), catalase, and glutathione peroxidase [71]. Why B content in TMNs is higher the normal level for thyroid and how an excess of B acts on thyroid gland are still to be cleared.

\subsection{Bismuth}

Trace metal $\mathrm{Bi}$ is the heaviest stable element. There is only limited information on Bi compounds effects and fate in the human body but $\mathrm{Bi}$ is seen as the least toxic heavy metal for humans. It is widely used in medical applications for its good antibacterial properties [22]. Until now Bi is not considered a human carcinogen. However, in recent publication Bi effects on thyroid function was shown [73]. Moreover, it was found that Bi replaces catalytic or structural metals such as iron, nickel and zinc in metalloproteins and the inorganic Bi derivatives can cause DNA single-strand breaks [74]. Why Bi content in TMNs is higher than normal level and how an excess of Bi acts on thyroid are still to be cleared.

\subsection{Cerium}

Ce is one among rare earth elements (REEs). REEs are a series of 17 chemical elements. They include scandium (Sc), yttrium (Y), lanthanum (La) and the lanthanide series from Ce to lutetium (Lu), in the periodic table. Their adverse health effects, including toxicity affected embryogenesis, fertilization, cytogenetic and redox endpoints, are well known $[75,76]$. However, the available information is insufficient to ascertain the mutagenicity and carcinogenicity of Ce or Ce compounds. Why Ce content in TMNs is higher than normal level and how an excess of Ce acts on thyroid are still to be cleared.

\subsection{Cobalt}

Health effects of high Co occupational, environmental, dietary and medical exposure are characterized by a complex clinical syndrome, mainly including neurological, cardiovascular and endocrine deficits, including hypothyroidism $[77,78]$. Co is genotoxic and carcinogenic, mainly caused by oxidative DNA damage by reactive oxygen species, perhaps combined with inhibition of DNA repair [79]. In our previous studies it was found a significant age-related increase of Co content in female thyroid [29]. Therefore, a goitrogenic and, probably, carcinogenic effect of excessive Co level in the thyroid of old females was assumed. Elevated level of Co in TMNs, observed in the present study, supports this conclusion. 


\subsection{Chromium}

The general population can be exposed to low levels of $\mathrm{Cr}$ primarily through consumption of food and to a lesser degree through inhalation of ambient air and ingestion of drinking water [80]. Cr-compounds are cytotoxic, genotoxic, and carcinogenic in nature. Some $\mathrm{Cr}$ forms, including hexavalent chromium $\left(\mathrm{Cr}^{6+}\right)$, are toxicants known for their carcinogenic effect in humans. They have been classified as certain or probable carcinogens by the International Agency for Research on Cancer [81]. The lung cancer risk is prevalent in pigment chromate handlers, ferrochromium production workers, stainless steel welders, and chrome-platers [82]. Except in Cr-related industries and associated environments, $\mathrm{Cr}$ intoxication from environmental exposure is not common. However, it was found, that drinking water supplies in many geographic areas contain chromium in the +3 and +6 oxidation states. Exposure of animals to $\mathrm{Cr}^{6+}$ in drinking water induced tumors in the mouse small intestine [83]. Many other animal experiments and in vitro studies demonstrate also that $\mathrm{Cr}$ can induce oxidative stress and exert cytotoxic effects [84]. Besides reactive oxygen species (ROS) generation, oxidative stress, and cytotoxic effects of $\mathrm{Cr}$ exposure, a variety of other changes like DNA damage, increased formation of DNA adducts and DNA-protein cross-links, DNA strand breaks, chromosomal aberrations and instability, disruption of mitotic cell division, chromosomal aberration, premature cell division, S or G2/M cell cycle phase arrest, and carcinogenesis also occur in humans or experimental test systems [82].

\subsection{Mercury}

In the general population, potential sources of $\mathrm{Hg}$ exposure include the inhalation of this metal vapor in the air, ingestion of contaminated foods and drinking water, and exposure to dental amalgam through dental care [85]. Hg is one of the most dangerous environmental pollutants [86]. The growing use of this metal in diverse areas of industry has resulted in a significant increase of environment contamination and episodes of human intoxication. Many experimental and occupational studies of $\mathrm{Hg}$ in different chemical states shown significant alterations in thyroid hormones metabolism and thyroid gland parenchyma $[87,88]$. Moreover, $\mathrm{Hg}$ was classified as certain or probable carcinogen by the International Agency for Research on Cancer [81]. For example, in Hg polluted area thyroid cancer incidence was almost 2 times higher than in adjacent control areas [89].

\subsection{Manganese}

Trace element $\mathrm{Mn}$ is a cofactor for numerous enzymes, playing many functional roles in living organisms. The Mncontaining enzyme, manganese superoxide dismutase (Mn-SOD), is the principal antioxidant enzyme which neutralizes the toxic effects of reactive oxygen species. It has been speculated that Mn interferes with thyroid hormone binding, transport, and activity at the tissue level [90]. There is opinion that Mn deficiencies in humans are rare and humans maintain stable tissue levels of this trace element [91]. It was reported that intracellular Mn content was positively correlated with manganese-containing superoxide dismutase (Mn-SOD), suggesting that the intracellular Mn level is associated with Mn-SOD activity [92]. However, an overall comprehension of Mn homeostasis and physiology, which is not yet acquired, is mandatory to establish Mn exact role in the thyroid malignant tumors etiology and metabolism.

\subsection{Molybdenum}

Mo is an essential trace element and part of a complex called molybdenum co-factor, which is required for three mammalian enzymes - xanthine oxidase, aldehyde oxidase and sulphite oxidase [93]. Mo-dependent enzymes operate in the oxidative system of thyroid epithelial cells and also play role in the release of $\mathrm{T}_{3}$ from the thyroid gland. However, there is data that even a slight increase Mo in the diet may accelerate and/or promote the process of thyroid cell transformation, thus acting as a tumor-promoting agent rather than a carcinogen [94]. Why Mo content in TMNs is higher than normal level and how an excess of Mo acts on thyroid are still to be cleared.

\subsection{Nickel}

The peripheral connection between inorganic $\mathrm{Ni}$ and autoimmune thyroid diseases was mentioned in the literature [95]. Moreover, well known that human exposure to highly nickel-polluted environments, such as those associated with nickel refining, electroplating, and welding, has the potential to produce not only thyroid diseases but a variety of pathologic effects. Among them are skin allergies, lung fibrosis, and cancer of the respiratory tract [96]. The exact mechanisms of nickel-induced carcinogenesis are not known. However, there is data that Ni-induced oxidative stress triggers cell proliferation, a process of great significance for cancer [97].

\subsection{Lead}

$\mathrm{Pb}$ is highly cytotoxic. It affects hormonal secretion and hormonal-induced cell responses. The epidemiological evidence for an association between $\mathrm{Pb}$ exposures and human cancer risk has been strengthened by many studies [98]. Why Pb content in TMNs is higher than normal level and how an excess of $\mathrm{Pb}$ acts on thyroid are still to be cleared. 


\subsection{Rubidium}

There is very little information about $\mathrm{Rb}$ effects on thyroid function. $\mathrm{Rb}$ as a monovalent cation $\mathrm{Rb}+\mathrm{is}$ transfered through membrane by the $\mathrm{Na}+\mathrm{K}+-\mathrm{ATPase}$ pump like $\mathrm{K}+$ and concentrated in the intracellular space of cells. Thus, $\mathrm{Rb}$ seems to be more intensivly concentrated in the intracellular space of cells. The sourse of Rb elevated level in tumor and adjacent to tumor tissue may be $\mathrm{Rb}$ environment overload. The excessive $\mathrm{Rb}$ intake may result a replacement of medium potassium by $\mathrm{Rb}$, which effects on iodide transport and iodoaminoacid synthesis by thyroid [99]. The sourse of $\mathrm{Rb}$ increase in TMNs tissue may be not only the excessive intake of this TE in organism from the environment, but also changed $\mathrm{Na}+\mathrm{K}+-$ ATPase or $\mathrm{H}+\mathrm{K}+-$ ATPase pump membrane transport systems for monovalent cations, which can be stimulated by endocrin system, including thyroid hormones [100]. It was found also that $\mathrm{Rb}$ has some function in immune responce [101] and that elevated concentration of $\mathrm{Rb}$ could modulate proliferative responses of the cell, as was shown for bone marrow leukocytes [102].These data partially clarify the possible role of Rb in etiology and pathogenesis of TMNs.

\subsection{Scandium and Samarium}

Sc and Sm are REEs (see, Cerium). REEs are not described as essential for humans, because no biochemical function has been directly connected to it. At this stage of our knowledge, no doubt that REEs overload negatively impact human health $[75,76]$. Why Sc content in TMNs is lower while Sm content is higher than normal level and how a deficiency of Sc and an excess of Sm acts on thyroid are still to be cleared.

\subsection{Selinium}

The high level of Se content found just in thyroid tissue adjacent to malignant tumor cannot be regarded as pure chance. The seleno-protein characterized as Se-dependent glutathione peroxidase (Se-GSH-Px) is involved in protecting cells from peroxidative damage. This enzyme may reduce tissue concentration of free radicals and hydroperoxides. It is particular important for the thyroid gland, because thyroidal functions involve oxidation of iodide, which is incorporated into thyreoglobulin, the precursor of the thyroid hormones. For oxidation of iodide thyroidal cells produce a specific thyroid peroxidase using of physiologically generated hydrogen-peroxide $\left(\mathrm{H}_{2} \mathrm{O}_{2}\right)$ as a cofactor [103]. It follows that the thyroid parenchyma must be continuously exposed to a physiological generation of $\mathrm{H}_{2} \mathrm{O}_{2}$ and in normal conditions must be a balance between levels of Se (as Se-GSH-Px) and $\mathrm{H}_{2} \mathrm{O}_{2}$. The elevated level of Se in thyroid tissue adjacent to malignant nodules was accompanied excessive accumulation of $\mathrm{Ag}, \mathrm{Co}, \mathrm{Hg}$, I, and $\mathrm{Rb}$ in comparison with "normal" values for these elements. Moreover, contents of Ag, $\mathrm{Co}, \mathrm{Hg}$, I, and Rb in adjacent tissue were higher than in malignant nodules. Thus, it might be assumed that the elevated level of Se is reaction of adjacent tissue on an increase in concentration of free radicals and hydroperoxides in thyroid gland and that this increase preceded the TMNs origination and development.

\subsection{Thallium}

$\mathrm{Tl}$ is a ubiquitous natural metal considered as the most toxic among trace elements. Moreover, $\mathrm{Tl}$ is a suspected human carcinogen [104]. Why Tl content in TMNs is higher than normal level and how an excess of Tl acts on thyroid are still to be cleared.

Our findings show that mass fraction of $\mathrm{Ag}, \mathrm{Al}, \mathrm{B}, \mathrm{Bi}, \mathrm{Ce}, \mathrm{Cr}, \mathrm{Hg}, \mathrm{Mn}, \mathrm{Mo}, \mathrm{Ni}, \mathrm{Pb}, \mathrm{Rb}, \mathrm{Sm}$, and $\mathrm{Tl}$ are significantly higher than in normal thyroid tissues (Table 2). Thus, it is plausible to assume that levels of these TEs in thyroid tissue can be used as tumor markers. However, this subject needs in additional studies.

\subsection{Limitations}

This study has several limitations. Firstly, analytical techniques employed in this study measure only $31 \mathrm{TEs}(\mathrm{Ag}, \mathrm{Al}, \mathrm{B}$, $\mathrm{Be}, \mathrm{Bi}, \mathrm{Cd}, \mathrm{Ce}, \mathrm{Co}, \mathrm{Cr}, \mathrm{Cs}, \mathrm{Fe}, \mathrm{Ga}, \mathrm{Hg}$, La, Li, Mn, Mo, Nd, Ni, Pb, Pr, Rb, Sb, Sc, Se, Sm, Sn, Tl, U, Y, and Zn) mass fractions. Future studies should be directed toward using other analytical methods which will extend the list of TEs investigated in "normal" thyroid and in pathologically altered tissue. Secondly, the sample size of TMNs group was relatively small and prevented investigations of TEs contents in this group using differentials like gender, histological types of TMNs, tumor functional activity, stage of disease, and dietary habits of patients with TMNs. Lastly, generalization of our results may be limited to Russian population. Despite these limitations, this study provides evidence on many TEs level alteration in malignant tumor and thyroid tissue adjacent to tumor and shows the necessity to continue TEs research of TMNs. 


\section{Conclusion}

In this work, TEs analysis was carried out in the tissue samples of TMNs (nodular and thyroid tissue adjacent to nodules) using a combination of non-destructive INAA-LLR and destructive ICP-MS methods. It was shown that this combination is an adequate analytical tool for the determination of 31 TEs content in the tissue samples of human thyroid in norm and pathology, including needle-biopsy specimens. It was observed that in malignant tissue the mass fraction of $\mathrm{Ag}$, $\mathrm{Al}$, $\mathrm{B}, \mathrm{Bi}, \mathrm{Ce}, \mathrm{Cr}, \mathrm{Hg}, \mathrm{Mn}, \mathrm{Mo}, \mathrm{Ni}, \mathrm{Pb}, \mathrm{Rb}, \mathrm{Sm}$, and Tl were approximately 11, 3.1, 4.6, 9.3, 3.5, 3.7, 17, 1.6, 3.5, 9.8, 4.9, 1.7, 3.8, and 3.3 times, respectively, higher, while Sc content 3.4 times lower than in normal tissues of the thyroid. In the "adjacent" group mean mass fractions of $\mathrm{Ag}, \mathrm{Bi}, \mathrm{Co}, \mathrm{Hg}$, Mo, $\mathrm{Ni}, \mathrm{Rb}$, and Se were approximately 33, 11, 1.7, 41, 2.4, 6.2, 2.5, and 1.4 times, respectively, higher, than in the "normal" group of samples. In malignant tumor Ag, Hg, and Se contents were approximately 3.1, 2.4, and 1.5 times, respectively, lower than in "adjacent" group of tissue samples. From this it follows that at least the excessive accumulation of $\mathrm{Ag}, \mathrm{Hg}$, and Se by thyroid tissue is likely to precede the TMNs origination and development. It was supposed that elevated levels of $\mathrm{Ag}, \mathrm{Al}, \mathrm{B}, \mathrm{Bi}, \mathrm{Ce}, \mathrm{Cr}, \mathrm{Hg}, \mathrm{Mn}, \mathrm{Mo}, \mathrm{Ni}, \mathrm{Pb}, \mathrm{Rb}, \mathrm{Sm}$, and $\mathrm{Tl}$ in nodular tissue could possibly be explored for differential diagnosis of benign and malignant thyroid nodules.

\section{Compliance with ethical standards}

\section{Acknowledgments}

The author is extremely grateful to Profs. Vtyurin BM and Medvedev VS, Medical Radiological Research Center, Obninsk, as well as to Dr. Choporov Yu, former Head of the Forensic Medicine Department of City Hospital, Obninsk, for supplying thyroid samples. The author is also grateful to Dr. Karandaschev V, Dr. Nosenko S, and Moskvina I, Institute of Microelectronics Technology and High Purity Materials, Chernogolovka, Russia, for their help in ICP-MS analysis.

\section{Disclosure of conflict of interest}

The author declares that he has no competing interests.

\section{Statement of ethical approval}

All studies were approved by the Ethical Committees of the Medical Radiological Research Centre (MRRC), Obninsk. All the procedures performed in studies involving human participants were in accordance with the ethical standards of the institutional and/or national research committee and with the 1964 Helsinki declaration and its later amendments, or with comparable ethical standards.

\section{References}

[1] Laha D, Nilubol N, Boufraqech M. New therapies for advanced thyroid cancer. Front Endocrinol (Lausanne). 2020; 11: 82.

[2] Buczyńska A, Sidorkiewicz I, Rogucki M, Siewko K, Adamska A, Kościuszko M, Maliszewska K, Kozłowska G, Szumowski P, Myśliwiec J, Krętowski A, Popławska-Kita A. Oxidative stress and radioiodine treatment of differentiated thyroid cancer. Sci Rep. 2021; 11: 17126.

[3] Prete A, Borges de Souza P, Censi S, Muzza M, Nucci N, Sponziello M. Update on Fundamental Mechanisms of Thyroid Cancer. Front Endocrinol (Lausanne). 2020; 11: 102.

[4] Barrea L, Gallo M, Ruggeri RM, Di Giacinto P, Sesti F, Prinzi N, Adinolfi V, Barucca V, Renzelli V, Muscogiuri G, Colao A, Baldelli R. Nutritional status and follicular-derived thyroid cancer: An update. Crit Rev Food Sci Nutr. 2021; 61(1): 25-59.

[5] Zaichick V. Iodine excess and thyroid cancer. J Trace Elem Exp Med. 1998; 11(4): 508-9.

[6] Zaichick V, Iljina T. Dietary iodine supplementation effect on the rat thyroid 131I blastomogenic action. In: Die Bedentung der Mengen- und Spurenelemente. 18. Arbeitstangung. Jena: Friedrich-Schiller-Universität. 1998; 294-306.

[7] Kim K, Cho SW, Park YJ, Lee KE, Lee D-W, Park SK. Association between iodine intake, thyroid function, and papillary thyroid cancer: A case-control study. Endocrinol Metab (Seoul). 2021; 36(4): 790-9. 
[8] Vargas-Uricoechea P, Pinzón-Fernández MV, Bastidas-Sánchez BE, Jojoa-Tobar E, Ramírez-Bejarano LE, MurilloPalacios J. Iodine status in the colombian population and the impact of universal salt iodization: a double-edged sword? J Nutr Metab. 2019; 6239243.

[9] Stojsavljević A, Rovčanin B, Krstić D, Borković-Mitić S, Paunović I, Diklić A, Gavrović-Jankulović M, Manojlović D. Risk assessment of toxic and essential trace metals on the thyroid health at the tissue level: The significance of lead and selenium for colloid goiter disease. Expo Health. 2019.

[10] Fahim YA, Sharaf NE, Hasani IW, Ragab EA, Abdelhakim HK. Assessment of thyroid function and oxidative stress state in foundry workers exposed to lead. J Health Pollut. 2020; 10(27): 200903.

[11] Liu M, Song J, Jiang Y, Lin Y, Peng J, Liang H, Wang C, Jiang J, Liu X, Wei W, Peng J, Liu S, Li Y, Xu N, Zhou D, Zhang Q, Zhang J. A case-control study on the association of mineral elements exposure and thyroid tumor and goiter. Ecotoxicol Environ Saf. 2021; 208: 111615.

[12] Zaichick V. Medical elementology as a new scientific discipline. J Radioanal Nucl Chem. 2006; 269: 303-9.

[13] Moncayo R, Moncayo H. A post-publication analysis of the idealized upper reference value of $2.5 \mathrm{mIU} / \mathrm{L}$ for TSH: Time to support the thyroid axis with magnesium and iron especially in the setting of reproduction medicine. BBA Clin. 2017; 7: 115-9.

[14] Beyersmann D, Hartwig A. Carcinogenic metal compounds: recent insight into molecular and cellular mechanisms. Arch Toxicol. 2008; 82(8): 493-512.

[15] Martinez-Zamudio R, Ha HC. Environmental epigenetics in metal exposure. Epigenetics. 2011; 6(7): 820-7.

[16] Zaĭchik V, Raibukhin YuS, Melnik AD, Cherkashin VI. Neutron-activation analysis in the study of the behavior of iodine in the organism. Med Radiol (Mosk). 1970; 15(1): 33-6.

[17] Ză̌chik V, Matveenko EG, Vtiurin BM, Medvedev VS. Intrathyroid iodine in the diagnosis of thyroid cancer. Vopr Onkol. 1982; 28(3): 18-24.

[18] Zaichick V, Tsyb AF, Vtyurin BM. Trace elements and thyroid cancer. Analyst. 1995; 120(3): 817-21.

[19] Zaichick V, Choporov YuYa. Determination of the natural level of human intra-thyroid iodine by instrumental neutron activation analysis. J Radioanal Nucl Chem. 1996; 207(1): 153-61.

[20] Zaichick V. In vivo and in vitro application of energy-dispersive XRF in clinical investigations: experience and the future. J Trace Elem Exp Med. 1998; 11(4): 509-10.

[21] Zaichick V, Zaichick S. Energy-dispersive X-ray fluorescence of iodine in thyroid puncture biopsy specimens. J Trace Microprobe Tech. 1999; 17(2): 219-232.

[22] Zaichick V. Relevance of, and potentiality for in vivo intrathyroidal iodine determination. Ann N Y Acad Sci. 2000; 904: 630-2.

[23] Zaichick V, Zaichick S. Normal human intrathyroidal iodine. Sci Total Environ. 1997; 206(1): 39-56.

[24] Zaichick V. Human intrathyroidal iodine in health and non-thyroidal disease. In: New aspects of trace element research (Eds: M.Abdulla, M.Bost, S.Gamon, P.Arnaud, G.Chazot). London: Smith-Gordon; and Tokyo: Nishimura. 1999; 114-9.

[25] Zaichick V, Zaichick S. Age-related changes of some trace element contents in intact thyroid of females investigated by energy dispersive X-ray fluorescent analysis. Trends Geriatr Healthc. 2017; 1(1): 31-8.

[26] Zaichick V, Zaichick S. Age-related changes of some trace element contents in intact thyroid of males investigated by energy dispersive X-ray fluorescent analysis. MOJ Gerontol Ger. 2017; 1(5): 00028.

[27] Zaichick V, Zaichick S. Age-related changes of $\mathrm{Br}, \mathrm{Ca}, \mathrm{Cl}, \mathrm{I}, \mathrm{K}, \mathrm{Mg}$, Mn, and $\mathrm{Na}$ contents in intact thyroid of females investigated by neutron activation analysis. Curr Updates Aging. 2017; 1: 5.1.

[28] Zaichick V, Zaichick S. Age-related changes of $\mathrm{Br}, \mathrm{Ca}, \mathrm{Cl}, \mathrm{I}, \mathrm{K}, \mathrm{Mg}, \mathrm{Mn}$, and $\mathrm{Na}$ contents in intact thyroid of males investigated by neutron activation analysis. J Aging Age Relat Dis. 2017; 1(1): 1002.

[29] Zaichick V, Zaichick S. Age-related changes of Ag, Co, Cr, Fe, Hg, Rb, Sb, Sc, Se, and Zn contents in intact thyroid of females investigated by neutron activation analysis. J Gerontol Geriatr Med. 2017; 3: 015.

[30] Zaichick V, Zaichick S. Age-related changes of Ag, Co, Cr, Fe, Hg, Rb, Sb, Sc, Se, and Zn contents in intact thyroid of males investigated by neutron activation analysis. Curr Trends Biomedical Eng Biosci. 2017; 4(4): 555644. 
[31] Zaichick V, Zaichick S. Effect of age on chemical element contents in female thyroid investigated by some nuclear analytical methods. MicroMedicine. 2018; 6(1): 47-61.

[32] Zaichick V, Zaichick S. Neutron activation and X-ray fluorescent analysis in study of association between age and chemical element contents in thyroid of males. Op Acc J Bio Eng Bio Sci. 2018; 2(4): 202-12.

[33] Zaichick V, Zaichick S. Variation with age of chemical element contents in females' thyroids investigated by neutron activation analysis and inductively coupled plasma atomic emission spectrometry. J Biochem Analyt Stud. 2018; 3(1): 1-10.

[34] Zaichick V, Zaichick S. Association between age and twenty chemical element contents in intact thyroid of males. SM Gerontol Geriatr Res. 2018; 2(1): 1014.

[35] Zaichick V, Zaichick S. Associations between age and 50 trace element contents and relationships in intact thyroid of males. Aging Clin Exp Res. 2018; 30(9): 1059-70.

[36] Zaichick V, Zaichick S. Possible role of inadequate quantities of intra-thyroidal bromine, rubidium and zinc in the etiology of female subclinical hypothyroidism. EC Gynaecology. 2018; 7(3): 107-15.

[37] Zaichick V, Zaichick S. Possible role of inadequate quantities of intra-thyroidal bromine, calcium and magnesium in the etiology of female subclinical hypothyroidism. Int Gyn and Women's Health. 2018; 1(3): IGWHC.MS.ID.000113.

[38] Zaichick V, Zaichick S. Possible role of inadequate quantities of intra-thyroidal cobalt, rubidium and zinc in the etiology of female subclinical hypothyroidism. Womens Health Sci J. 2018; 2(1): 000108.

[39] Zaichick V, Zaichick S. Association between female subclinical hypothyroidism and inadequate quantities of some intra-thyroidal chemical elements investigated by X-ray fluorescence and neutron activation analysis. Gynaecology and Perinatology. 2018; 2(4): 340-55.

[40] Zaichick V, Zaichick S. Investigation of association between the high risk of female subclinical hypothyroidism and inadequate quantities of twenty intra-thyroidal chemical elements. Clin Res: Gynecol Obstet. 2018; 1(1): 118.

[41] Zaichick V, Zaichick S. Investigation of association between the high risk of female subclinical hypothyroidism and inadequate quantities of intra-thyroidal trace elements using neutron activation and inductively coupled plasma mass spectrometry. Acta Scientific Medical Sciences. 2018; 2(9): 23-37.

[42] Zaichick V. Comparison between trace element contents in macro and micro follicular colloid goiter using neutron activation analysis. Journal of Clinical Research and Clinical Case Reports. 2021; 2(2): 1-7.

[43] Zaichick V, Zaichick S. Determination of fifty trace element contents in macro and micro follicular colloid nodular goiter. American Journal of Biomedical Science \& Research. 2021; 13(6): 639-50.

[44] Zaichick V. Trace element contents in thyroid of patients with diagnosed nodular goiter investigated by instrumental neutron activation analysis. Journal of Medical Research and Health Sciences. 2021; 4(8): 1405-17.

[45] Zaichick V. Determination of fifty trace element contents in normal and goitrous thyroid using a combination of instrumental neutron activation analysis and inductively coupled plasma mass spectrometry. Metallomics Research. 2021; 1: 1-19.

[46] Zaichick V. Comparison of trace element contents in normal and adenomatous thyroid investigated using instrumental neutron activation analysis. Saudi J Biomed Res. 2021; 6(11): 246-55

[47] Zaichick V. Evaluation of fifty trace element contents in thyroid adenomas using a combination of instrumental neutron activation analysis and inductively coupled plasma mass spectrometry. Journal of Cancer and Oncology Research. 2021; 2(3): 1-11.

[48] Zaichick V. Evaluation of ten trace elements in Riedel's Struma using neutron activation analysis. Mod Res Clin Canc Prev. 2021; 1(1): 1-6.

[49] Zaichick V. Comparison of trace element contents in normal thyroid and thyroid with Hashimoto's thyroiditis using neutron activation analysis. World Journal of Advanced Research and Reviews. 2021; 12(01): 503-11.

[50] Zaichick V, Zaichick S. Instrumental effect on the contamination of biomedical samples in the course of sampling. The Journal of Analytical Chemistry. 1996; 51(12): 1200-5.

[51] Zaichick V, Zaichick S. A search for losses of chemical elements during freeze-drying of biological materials. J Radioanal Nucl Chem. 1997; 218(2): 249-53. 
[52] Zaichick S, Zaichick V. The effect of age on $\mathrm{Ag}, \mathrm{Co}, \mathrm{Cr}, \mathrm{Fe}, \mathrm{Hg}, \mathrm{Sb}, \mathrm{Sc}, \mathrm{Se}$, and Zn contents in intact human prostate investigated by neutron activation analysis. App Radiat Isot. 2011; 69(6): 827-33.

[53] Zaichick V, Zaichick S. Relations of the neutron activation analysis data to morphometric parameters in pediatric and nonhyperplastic young adult prostate glands. Advances in Biomedical Science and Engineering. 2014; 1(1): 26-42.

[54] Zaichick V, Zaichick S. Variations in concentration and histological distribution of Ag, Co, Cr, Fe, Hg, Rb, Sb, Sc, Se, and $\mathrm{Zn}$ in nonhyperplastic prostate gland throughout adulthood. Jacobs Journal of Cell and Molecular Biology. 2016; 2(1): 1-16.

[55] Zaichick S, Zaichick V, Nosenko S, Moskvina I. Mass fractions of 52 trace elements and zinc trace element content ratios in intact human prostates investigated by inductively coupled plasma mass spectrometry. Biol Trace Elem Res. 2012; 149(2): 171-83.

[56] Zaichick V, Zaichick S. The distribution of 54 trace elements including zinc in pediatric and nonhyperplastic young adult prostate gland tissues. Journal of Clinical and Laboratory Investigation Updates. 2014; 2(1): 1-15.

[57] Zaichick V, Zaichick S. Age-related changes in concentration and histological distribution of 54 trace elements in nonhyperplastic prostate of adults. Int Arch Urol Complic. 2016; 2(2): 019.

[58] Zaichick S, Zaichick V. The effect of age and gender on 37 chemical element contents in scalp hair of healthy humans. Biol Trace Elem Res. 2010; 134(1): 41-54.

[59] Zaichick V. Applications of synthetic reference materials in the medical Radiological Research Centre. Fresenius J Anal Chem. 1995; 352: 219-23.

[60] Korelo AM, Zaichick V. Software to optimize the multielement INAA of medical and environmental samples. In: Activation Analysis in Environment Protection. Dubna, Russia: Joint Institute for Nuclear Research. 1993; 32632.

[61] Lansdown AB. Critical observations on the neurotoxicity of silver. Crit Rev Toxicol. 2007; 37(3): $237-50$.

[62] De Vos S, Waegeneers N, Verleysen E, Smeets K, Mast J. Physico-chemical characterisation of the fraction of silver (nano)particles in pristine food additive E174 and in E174-containing confectionery. Food Addit Contam Part A Chem Anal Control Expo Risk Assess. 2020; 37(11): 1831-46.

[63] Hadrup N, Sharma AK, Loeschner K. Toxicity of silver ions, metallic silver, and silver nanoparticle materials after in vivo dermal and mucosal surface exposure: A review. Regul Toxicol Pharmacol. 2018; 98: 257-67.

[64] Lansdown AB. Silver in health care: antimicrobial effects and safety in use. Curr Probl Dermatol. 2006; 33: 17-34.

[65] Drake PL, Hazelwood KJ. Exposure-related health effects of silver and silver compounds: a review. Ann Occup Hyg. 2005; 49(7): 575-85.

[66] Katarzyńska-Banasik D, Grzesiak M, Kowalik K, Sechman A. Administration of silver nanoparticles affects ovarian steroidogenesis and may influence thyroid hormone metabolism in hens (Gallus domesticus). Ecotoxicol Environ Saf. 2021; 208: 111427.

[67] Igbokwe IO, Igwenagu E, Igbokwe NA. Aluminium toxicosis: a review of toxic actions and effects. Interdiscip Toxicol. 2019; 12(2): 45-70.

[68] Orihuela D. Aluminium effects on thyroid gland function: iodide uptake, hormone biosynthesis and secretion. J Inorg Biochem. 2011; 105(11): 1464-8.

[69] Benvenga S, Elia G, Ragusa F, Paparo SR, Sturniolo MM, Ferrari SM, Antonelli A, Fallahi P. Endocrine disruptors and thyroid autoimmunity. Best Pract Res Clin Endocrinol Metab. 2020; 34(1): 101377.

[70] Naghii MR, Mofid M, Asgari AR, Hedayati M, Daneshpour MS. Comparative effects of daily and weekly boron supplementation on plasma steroid hormones and proinflammatory cytokines. J Trace Elem Med Biol. 2011; 25: 54-8.

[71] Pizzorno L. Nothing boring about boron. Integr Med (Encinitas). 2015; 14: 35-48.

[72] Mohan R. Green bismuth. Nature Chem. 2010; 2: 336.

[73] Noori Jassim AM, Mohammed Al Kazazz FF, Khalaf Ali A. Biochemical study for bismuth oxide and tellurium nanoparticles on thyroid hormone levels in serum and saliva of patients with chronic renal failure. Int J Chem Sci. 2013; 11(3): 1299-313. 
[74] Thomas F, Bialek B, Hensel R. Medical Use of Bismuth: the Two Sides of the Coin. J Clinic Toxicol. $2012 ;$ S3: 004.

[75] Zaichick S, Zaichick V, Karandashev V, Nosenko S. Accumulation of rare earth elements in human bone within the lifespan. Metallomics. 2011; 3: 186-94.

[76] Pagano G, Siciliano A, Gravina M, Palumbo A, Castellano I, Migliaccio O, Thomas PJ, Guida M, Tommasi F, Trifuoggi M. Heavy rare earth elements affect early life stages in Paracentrotus lividus and Arbacia lixula sea urchins. Environ Res. 2017; 154: 240-6.

[77] Leyssens L, Vinck B, Van Der Straeten C, Wuyts F, Maes L. Cobalt toxicity in humans-A review of the potential sources and systemic health effects. Toxicology. 2017; 387: 43-56.

[78] Yu R. Cobalt Toxicity, An overlooked Cause of Hypothyroidism. J Endocrinol Thyroid Res. 2017; 1(3): 1-4.

[79] Simonsen LO, Harbak H, Bennekou P. Cobalt metabolism and toxicology--a brief update. Sci Total Environ. 2012; 432: $210-5$.

[80] Linos A, Petralias A, Christophi CA, Christoforidou E, Kouroutou P, Stoltidis M, et al. Oral ingestion of hexavalent chromium through drinking water and cancer mortality in an industrial area of Greece--an ecological study. Environ Health 2011; 10: 50.

[81] Järup L. Hazards of heavy metal contamination. Br Med Bull. 2003; 68: 167-82.

[82] Nigam A, Priya S, Bajpai P, Kumar S. Cytogenomics of hexavalent chromium (Cr 6+) exposed cells: a comprehensive review. Indian J Med Res. 2014; 139(3): 349-70.

[83] Zhitkovich A. Chromium in drinking water: sources, metabolism, and cancer risks. Chem Res Toxicol. 2011; 4(10): 1617-29.

[84] Ding SZ, Yang YX, Li XL, Michelli-Rivera A, Han SY, Wang L, Pratheeshkumar P, Wang X, Lu J, Yin YQ, Budhraja A, Hitron AJ. Epithelial-mesenchymal transition during oncogenic transformation induced by hexavalent chromium involves reactive oxygen species-dependent mechanism in lung epithelial cells. Toxicol Appl Pharmacol. 2013; 269(1): 61-71.

[85] Kim S-A, Kwon YM, Kim S, Joung H. Assessment of dietary mercury intake and blood mercury levels in the Korean population: Results from the Korean National Environmental Health Survey 2012-2014. Int J Environ Res Public Health. 2016; 13(9): 877.

[86] Clarkson TW, Magos L The toxicology of mercury and its chemical compounds. Crit Rev Toxicol. 2006; 36: 609662 .

[87] Correia MM, Chammas MC, Zavariz JD, Arata A, Martins LC, Marui S, Pereira LAA. Evaluation of the effects of chronic occupational exposure to metallic mercury on the thyroid parenchyma and hormonal function. Int Arch Occup Environ Health. 2020; 93(4): 491-502.

[88] Hu O, Han X, Dong G, Yan W, Wang X, Bigambo FM, Fang K, Xia Y, Chen T, Wang X. Association between mercury exposure and thyroid hormones levels: A meta-analysis. Environ Res. 2021; 196: 110928.

[89] Malandrino P, Russo M, Ronchi A, Minoia C, Cataldo D, Regalbuto C, Giordano C, Attard M, Squatrito S, Trimarchi $\mathrm{F}$, Vigneri R. Increased thyroid cancer incidence in a basaltic volcanic area is associated with non-anthropogenic pollution and biocontamination. Endocrine. 2016; 53(2): 471-9.

[90] Soldin OP, Aschner M. Effects of manganese on thyroid hormone homeostasis. Neurotoxicology. 2007; 28: 951-6.

[91] Aschner JL, Aschner M. Nutritional aspects of manganese homeostasis. Mol Aspects Med. 2005; 26: 353-62.

[92] Hasegawa S, Koshikawa M, Takahashi I, Hachiya M, Furukawa T, Akashi M, Yoshida S, Saga T. Alterations in manganese, copper, and zinc contents, and intracellular status of the metal-containing superoxide dismutase in human mesothelioma cells. J Trace Elem Med Biol. 2008; 22: 248-55.

[93] Sardesai VM. Molybdenum: an essential trace element. Nutr Clin Pract. 1993; 8: 277-81.

[94] Luca E, Fici L, Ronchi A, Marandino F, Rossi ED, Caristo ME, Malandrino P, Russo M, Pontecorvi A, Vigneri R, Moretti F. Intake of boron, cadmium, and molybdenum enhances rat thyroid cell transformation. J Exp Clin Cancer Res. 2017; 36: 73

[95] Takir M, Turkoglu 0, Turkoglu Z. Thyroid hormone and ultrasonographical analyses in patients with nickel allergy. EJMO. 2017; 1(3): 145-8. 
[96] Kasprzak KS, Sunderman FW, Salnikow K. Nickel carcinogenesis. Mutation Research/Fundamental and Molecular Mechanisms of Mutagenesis. 2003; 533(1-2): 67-97.

[97] Mohammadi-Bardbori A, Rannug A. Arsenic, cadmium, mercury and nickel stimulate cell growth via NADPH oxidase activation. Chem Biol Interact. 2014; 224: 183-8.

[98] Silbergeld EK. Facilitative mechanisms of lead as a carcinogen. Mutat Res-Fund Mol M. 2003; 533: 121-33.

[99] Haibach H, Greer MA. Effect of replacement of medium potassium by sodium, cesium or rubidium on in vitro iodide transport and iodoamino acid synthesis by rat thyroid. Proc Soc Exp Biol Med. 1973; 143(1): 114-7.

[100] York DA, Bray GA, Yukimura Y. An enzymatic defect in the obese (ob/ob) mouse: Loss of thyroid-induced sodiumand potassium-dependent adenosinetriphosphatase. Proc Natl Acad Sci USA. 1978; 75(1): 477-81.

[101] Jones JM, Yeralan O, Hines G, Maher M, Roberts DW, Benson W. Effects of lithium and rubidium on immune responses of rats. Toxicol Lett. 1990; 52(2): 163-8.

[102] Petrini M, Vaglini F, Carulli G, Azzarà A, Ambrogi F, Grassi B. Rubidium is a possible supporting element for bone marrow leukocyte differentiation. Haematologica. 1990; 75(1): 27-31.

[103] Aaseth J, Frey H, Glattre E, Norheim G, Ringstad J, Thomassen Y: Selenium concentrations in the human thyroid gland. Biol Trace Elem Res. 1990; 24(2-3): 147-52.

[104] Emsley J. Thallium. The element of murder. A history of poison. New York: Oxford University Press Inc. 2005. 